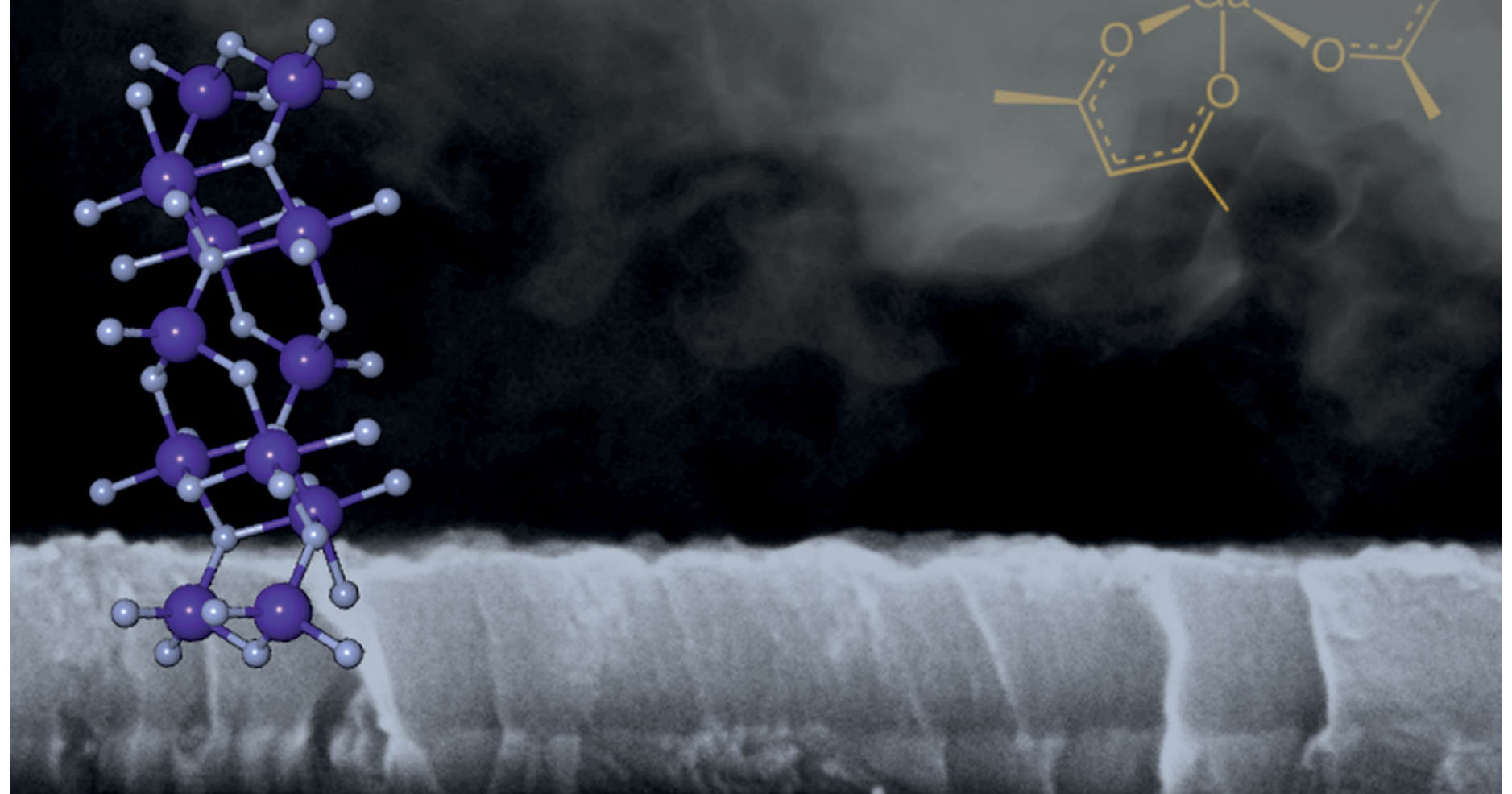

Showcasing research from the Photovoltaic Systems Group, Center for Energy, Austrian Institute of Technology (AIT), in collaboration with the University of Vienna and the Humboldt University of Berlin

Nanocrystalline $\mathrm{Ga}_{2} \mathrm{O}_{3}$ films deposited by spray pyrolysis from water-based solutions on glass and TCO substrates

The work presents a low-cost and up-scalable fabrication method for high-quality gallium oxide films using spray-pyrolysis from water-based solutions and moderate temperatures. The interplay between solution chemistry, process parameters and film properties is elucidated.

\section{As featured in:}

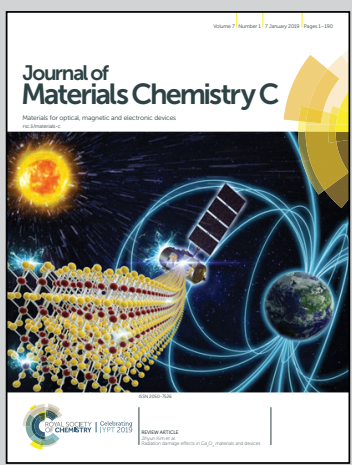

See Nina Winkler,

Theodoros Dimopoulos et al., J. Mater. Chem. C, 2019, 7, 69. 
Check for updates

Cite this: J. Mater. Chem. C, 2019, 7, 69

Received 20th August 2018, Accepted 21st September 2018

DOI: $10.1039 / \mathrm{c} 8 \mathrm{tc0} 0157 \mathrm{a}$

rsc.li/materials-c

\title{
Nanocrystalline $\mathrm{Ga}_{2} \mathrm{O}_{3}$ films deposited by spray pyrolysis from water-based solutions on glass and TCO substrates
}

\author{
Nina Winkler, (D)*ab Rachmat Adhi Wibowo, (D) a Wolfgang Kautek, (D) ${ }^{\mathrm{b}}$ \\ Giovanni Ligorio, (D) ${ }^{c}$ Emil J. W. List-Kratochvil (D) ${ }^{c}$ and Theodoros Dimopoulos (D) *a
}

\begin{abstract}
A low-cost and up-scalable fabrication method for high-quality gallium oxide films using spray pyrolysis from water-based solutions and moderate temperatures is presented. The solution chemistry and spraying process parameters were optimized to obtain homogeneous films on glass and three different transparent conducting oxide substrates. Structural and optical film properties of the deposited nanocrystalline $\mathrm{Ga}_{2} \mathrm{O}_{3}$ were evaluated by scanning electron microscopy, grazing-incidence X-ray diffraction, atomic force microscopy and optical spectroscopy. The elemental composition of the surface and the bulk film was analyzed by $\mathrm{X}$-ray photoemission spectroscopy depth profiling. To show the applicability of the deposited $\mathrm{Ga}_{2} \mathrm{O}_{3}$ in electronic devices, the electronic valence region of the material was studied by ultraviolet photoemission spectroscopy, resulting in an energy level diagram of the material.
\end{abstract}

\section{Introduction}

Gallium oxide $\left(\mathrm{Ga}_{2} \mathrm{O}_{3}\right)$, depending on the growth conditions and the crystal structure, is either an insulator or an n-type, wide-band gap semiconductor. There are several polymorphs of $\mathrm{Ga}_{2} \mathrm{O}_{3}$, but the most stable under ambient conditions, which has attracted the most attention, is monoclinic $\beta-\mathrm{Ga}_{2} \mathrm{O}_{3} .{ }^{1}$

According to Varley et al. ${ }^{2}$ the $\mathrm{n}$-type conductivity of $\beta-\mathrm{Ga}_{2} \mathrm{O}_{3}$ originates from the unintentional incorporation of impurities during the deposition process rather than oxygen vacancies, which act solely as deep donors. An extensive review of $\mathrm{Ga}_{2} \mathrm{O}_{3}$ material properties, processing routes and devices was recently published by Pearton et al. ${ }^{3}$ while $\beta-\mathrm{Ga}_{2} \mathrm{O}_{3}$, in particular, was reviewed by Park et al. ${ }^{4}$ The material has, indeed, found a wide range of applications in various disciplines. Single-crystals of $\mathrm{Ga}_{2} \mathrm{O}_{3}$ were synthesized by low-cost, melt growth techniques ${ }^{5}$ and were implemented in power electronic devices with high breakdown voltages, as replacements for the costly $\mathrm{SiC}$ and GaN. ${ }^{6}$ Thin layers of $\mathrm{Ga}_{2} \mathrm{O}_{3}$ have been applied in solar cells, for example as an ultrathin tunneling layer in dye-sensitized solar cells ${ }^{7}$ or as a passivation layer on silicon solar cells. ${ }^{8}$ Due to its low electron affinity, $\mathrm{Ga}_{2} \mathrm{O}_{3}$ was also successfully applied as an

\footnotetext{
${ }^{a}$ AIT Austrian Institute of Technology, Center for Energy, Photovoltaic Systems, Giefinggasse 6, A-1210 Vienna, Austria. E-mail: nina.winkler@ait.ac.at, theodoros.dimopoulos@ait.ac.at

${ }^{b}$ University of Vienna, Department of Physical Chemistry, Währinger Straße 42, A-1090 Vienna, Austria

${ }^{c}$ Humboldt-Universität zu Berlin, Institut für Physik, Institut für Chemie, IRIS Adlershof, Brook-Taylor-Str. 6, 12489 Berlin, Germany
}

n-type buffer layer in $\mathrm{Cu}_{2} \mathrm{O}$-type heterojunction solar cells. ${ }^{9,10}$ Due to its transparency in the deep UV spectral region, semiconducting $\beta-\mathrm{Ga}_{2} \mathrm{O}_{3}$ is especially attractive for solar-blind UV detectors ${ }^{11,12}$ or as a window layer in optoelectronic devices. ${ }^{13}$ Besides that, its high thermal (melting point $1715{ }^{\circ} \mathrm{C}$ ) ${ }^{1}$ and chemical stability renders it applicable for sensors that operate under harsh conditions, such as reductive gas sensors. ${ }^{14} \beta-\mathrm{Ga}_{2} \mathrm{O}_{3}$ can further be applied in water splitting devices, due to its photocatalytic properties. ${ }^{15}$

Gallium oxide films are often prepared by vacuum techniques, such as metal-organic chemical vapor deposition (MOCVD), ${ }^{16}$ molecular beam epitaxy (MBE), ${ }^{17}$ pulsed laser deposition (PLD) ${ }^{18}$ or atomic layer deposition (ALD). ${ }^{19}$ For lowering the processing costs, solution-based techniques are very attractive. Spray pyrolysis is a vacuum-free, easily up-scalable process, where the film deposition involves a precursor solution, sprayed in a carrier gas that is directed onto a heated substrate. For the droplet generation, there are various techniques available. Among them, ultrasonic agitation results in small droplet sizes $(10-20 \mu \mathrm{m})$ with a uniform size distribution. ${ }^{20}$ Smaller solvent droplets are evaporated faster and the precursor salt decomposes before reaching the substrate surface, giving rise to film formation from the vapor phase.

This technique has already been applied for the deposition of $\mathrm{Ga}_{2} \mathrm{O}_{3}$ films, ${ }^{12,21-26}$ but most of the reported works have used toxic or flammable organic solvents like methanol ${ }^{24}$ and ethanol ${ }^{12,22}$ in the precursor solution. Avoiding organic solvents is highly desired, due to safety risks and environmental considerations, but using water-based solutions is a challenging task, demanding 
high deposition temperatures - above $400{ }^{\circ} \mathrm{C}$ - in order to achieve high-quality films. ${ }^{23,26}$ This is due to the high amount of heat that is required to evaporate water, because of the strong $\mathrm{H}-\mathrm{O}-\mathrm{H}$ hydrogen bonds and high boiling point. ${ }^{27}$ Further, no additional heat is transferred through exothermic burning, as compared to organic solvents. Another issue concerns the high surface tension of water, which leads to larger droplet sizes that require high evaporation temperatures.

Reports on using water-based solutions for the spray pyrolysis of $\mathrm{Ga}_{2} \mathrm{O}_{3}$ films at deposition temperatures below $400{ }^{\circ} \mathrm{C}$ are very limited, ${ }^{21,25}$ and they lack a comprehensive structural, electronic and chemical characterization of the deposited material.

This study explains for the first time how the chemistry of a water-based precursor solution and the spraying process parameters should be adjusted to obtain high-quality $\mathrm{Ga}_{2} \mathrm{O}_{3}$ films on bare glass and glass coated with different transparent conductive oxides (TCOs), while maintaining a moderate deposition temperature below $400{ }^{\circ} \mathrm{C}$. Structural properties of the deposited $\mathrm{Ga}_{2} \mathrm{O}_{3}$ were analyzed in detail by scanning electron microscopy (SEM), atomic force microscopy (AFM) and grazing incidence X-ray diffraction (GIXRD). The chemical composition of the films on the surface and in the bulk was investigated by X-ray photoelectron spectroscopy (XPS). Optical properties of the material were examined by ultraviolet/visible/ infrared (UV/Vis/IR) spectroscopy. To demonstrate the potential of the spray-deposited $\beta-\mathrm{Ga}_{2} \mathrm{O}_{3}$ in electronic devices, where a precise band alignment is crucial, ultraviolet photoelectron spectroscopy (UPS) spectra were recorded and an energy level diagram was constructed.

\section{Experimental}

\subsection{Equipment}

For the spray pyrolysis, a Sono-Tek ExactaCoat ${ }^{\circledR}$ system was used, equipped with a Sono-Tek Impact ${ }^{\mathbb{R}}$ ultrasonic nozzle in the horizontal geometry, operating at $120 \mathrm{kHz}$. The scanning speed of the nozzle over the substrate was $25 \mathrm{~mm} \mathrm{~s}^{-1}$ and the substrate to nozzle distance was $20 \mathrm{~cm}$. All films were deposited using air as the carrier gas, with a pressure of 0.5 bar.

The film thickness and morphology for each layer was evaluated by SEM (Zeiss Ultra 40) at an accelerating voltage of $5 \mathrm{kV}$. The surface topography was measured by AFM (Molecular Imaging, PicoPlus) in the tapping mode. The crystal structure was investigated by GIXRD (ThermoFisher Scientific ARL Equinox 100) at an angle of $1^{\circ}$, using $\mathrm{Cu}-\mathrm{K}_{\alpha}(\lambda=1.5419 \AA)$ radiation. Transmittance spectra in the range between 300 and $1100 \mathrm{~nm}$ were recorded by a Fourier transform infrared spectroscopy instrument (FTIR, Bruker Vertex 70), while in the range between 200 and $900 \mathrm{~nm}$, they were recorded by a UV/Vis/IR spectroscopy instrument (Thermo Electron Corporation Nicolet evolution 100). XPS was measured in a JEOL JPS-9030 photoelectron spectrometer system using a monochromatic $\mathrm{Al} \mathrm{K}_{\alpha}$ $(1486 \mathrm{eV})$ excitation source. XPS depth profiling was performed using an $\mathrm{Ar}^{+}$ion source with $3 \mathrm{~mA}$ ion current and $300 \mathrm{~V}$ acceleration voltage. UPS spectra were measured using a hemispherical electron analyzer (Scienta SES 100) with a He I line exciton energy of $21.2 \mathrm{eV}$. The secondary electron cut-off (SECO) was measured with a bias voltage of $-10 \mathrm{~V}$. The energy position of the SECO and the low binding energy onset of emission of the highest occupied molecular level were determined through linear extrapolation of the peak half-maximum towards the background. The sheet-resistance was measured using a 4-point probe setup (Süss MicroTec probes) connected to a semiconductor parameter analyser (Agilent $4156 \mathrm{C}$ ).

\subsection{Substrate preparation}

Borosilicate glass substrates (Schott Nexterion ${ }^{\circledR} \mathrm{D}, 7.5 \times 2.5 \mathrm{~cm}^{2}$ ) and pure $\mathrm{SiO}_{2}$ substrates (Plan Optik, $2.5 \times 2.5 \mathrm{~cm}^{2}$ ) were ultrasonically cleaned for 30 minutes at $50{ }^{\circ} \mathrm{C}$ in Hellmanex ${ }^{\circledR}$ III washing solution. The substrates were afterwards rinsed with deionized water (DI, $18 \mathrm{M} \Omega \mathrm{cm}^{-1}$ ), isopropanol and dried in an air stream. Commercial tin-doped indium oxide (ITO, SigmaAldrich 703192, 8-12 $\Omega \mathrm{Sq}^{-1}$ ) and fluorine-doped tin oxide (FTO, Sigma-Aldrich 735140-5EA, 5-7 $\Omega \mathrm{Sq}^{-1}$ ) glass substrates were rinsed with isopropanol and dried in an air stream.

Indium zinc oxide (IZO) substrates were prepared by spray pyrolysis on borosilicate substrates following a previously reported recipe. ${ }^{28}$ In brief, a precursor solution containing $0.2 \mathrm{M}$ zinc acetate dihydrate $\left(\mathrm{ZnAc}_{2} \cdot 2 \mathrm{H}_{2} \mathrm{O}\right.$, Sigma-Aldrich 96459), $4 \mathrm{~mol} \%$ indium acetate ( $\operatorname{InAc}_{3}$, Sigma-Aldrich 510270$)$ and 8 vol\% acetic acid (HAc, Sigma-Aldrich A6283) was used. Flow rate and

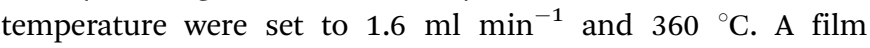
thickness of $1.8 \mu \mathrm{m}$ resulted in a sheet resistance of $20.7 \Omega \mathrm{Sq}^{-1}$ with an average transparency of $72 \%$ in the visible range between 450 and $700 \mathrm{~nm}$.

\subsection{Precursor solution preparation}

For the optimized $0.04 \mathrm{M}$ precursor solution, gallium acetylacetonate $\left(\mathrm{Ga}(\mathrm{acac})_{3}\right)$ was dissolved in deionized water containing 3.5 $\mathrm{M}$ acetic acid. The solution was placed in an ultrasonic bath for $1 \mathrm{~h}$ at room temperature $\left(25^{\circ} \mathrm{C}\right)$ for complete dissolution of the precursor salt and was then directly used for the spray pyrolysis.

\section{Results and discussion}

\subsection{Spray pyrolysis of gallium oxide}

3.1.1 Aqueous solution chemistry of $\mathrm{Ga}^{3+}$. As stated earlier, one aim of this work was to use only aqueous solutions for the spray pyrolysis of $\mathrm{Ga}_{2} \mathrm{O}_{3}$. This is a challenge due to the strong tendency of $\mathrm{Ga}^{3+}$ ions for hydrolysis, resulting in the formation of hydroxide species and leading to the precipitation of $\mathrm{Ga}(\mathrm{OH})_{3}$ in the solution. ${ }^{29}$ This behavior is illustrated by modelling the speciation of gallium in an aqueous solution with reactions and complex stability constants displayed in Table 1 and using the speciation modelling software Species from the Analytical Division of IUPAC. ${ }^{30}$ All used complex stability constants were measured under similar ionic strengths as those in our present study. ${ }^{31-33}$ Fig. 1(a) shows that the formation of the $\left[\mathrm{Ga}(\mathrm{OH})_{3}\right]^{0}$ complex begins at $\mathrm{pH} \sim 2$ and at $\mathrm{pH}$ larger than $\sim 3.5$ only $\mathrm{Ga}(\mathrm{OH})_{3}$ is present, which precipitates in solution. In an 
Table 1 Complex stability reactions of gallium in water/acetic acid

\begin{tabular}{|c|c|c|}
\hline Reaction & $\log \beta\left(25^{\circ} \mathrm{C}\right)$ & Ref. \\
\hline$\overline{\mathrm{H}_{2} \mathrm{O} \leftrightarrow \mathrm{H}^{+}+\mathrm{OH}^{-}}$ & -13.73 & 33 \\
\hline $\mathrm{Ga}^{3+}+\mathrm{H}_{2} \mathrm{O} \leftrightarrow[\mathrm{Ga}(\mathrm{OH})]^{2+}+\mathrm{H}^{+}$ & -3.73 & 31 \\
\hline $\mathrm{Ga}^{3+}+2 \mathrm{H}_{2} \mathrm{O} \leftrightarrow\left[\mathrm{Ga}(\mathrm{OH})_{2}\right]^{+}+2 \mathrm{H}^{+}$ & -7.15 & 31 \\
\hline $\mathrm{Ga}^{3+}+3 \mathrm{H}_{2} \mathrm{O} \leftrightarrow\left[\mathrm{Ga}(\mathrm{OH})_{3}\right]^{0}+3 \mathrm{H}^{+}$ & -8.20 & 32 \\
\hline $\mathrm{Ga}^{3+}+4 \mathrm{H}_{2} \mathrm{O} \leftrightarrow\left[\mathrm{Ga}(\mathrm{OH})_{4}\right]^{-}+4 \mathrm{H}^{+}$ & -17.30 & 32 \\
\hline $\mathrm{HAc} \leftrightarrow \mathrm{H}^{+}+\mathrm{Ac}^{-}$ & -4.49 & 33 \\
\hline $\mathrm{Ga}^{3+}+\mathrm{HAc} \leftrightarrow[\mathrm{GaAc}]^{2+}+\mathrm{H}^{+}$ & -2.08 & 33 \\
\hline $2 \mathrm{Ga}^{3+}+\mathrm{HAc}+2 \mathrm{H}_{2} \mathrm{O} \leftrightarrow\left[\mathrm{Ga}_{2}(\mathrm{OH})_{2} \mathrm{Ac}\right]^{3+}+3 \mathrm{H}^{+}$ & -5.65 & 33 \\
\hline $\mathrm{Ga}^{3+}+\mathrm{Acac}^{-} \leftrightarrow[\mathrm{Ga}(\mathrm{acac})]^{2+}$ & 23.65 & 34 \\
\hline $\mathrm{Ga}^{3+}+2 \mathrm{Acac}^{-} \leftrightarrow\left[\mathrm{Ga}(\mathrm{acac})_{2}\right]^{+}$ & 17.27 & 34 \\
\hline $\mathrm{Ga}^{3+}+3 \mathrm{Acac}^{-} \leftrightarrow\left[\mathrm{Ga}(\mathrm{acac})_{3}\right]^{0}$ & 9.29 & 34 \\
\hline
\end{tabular}
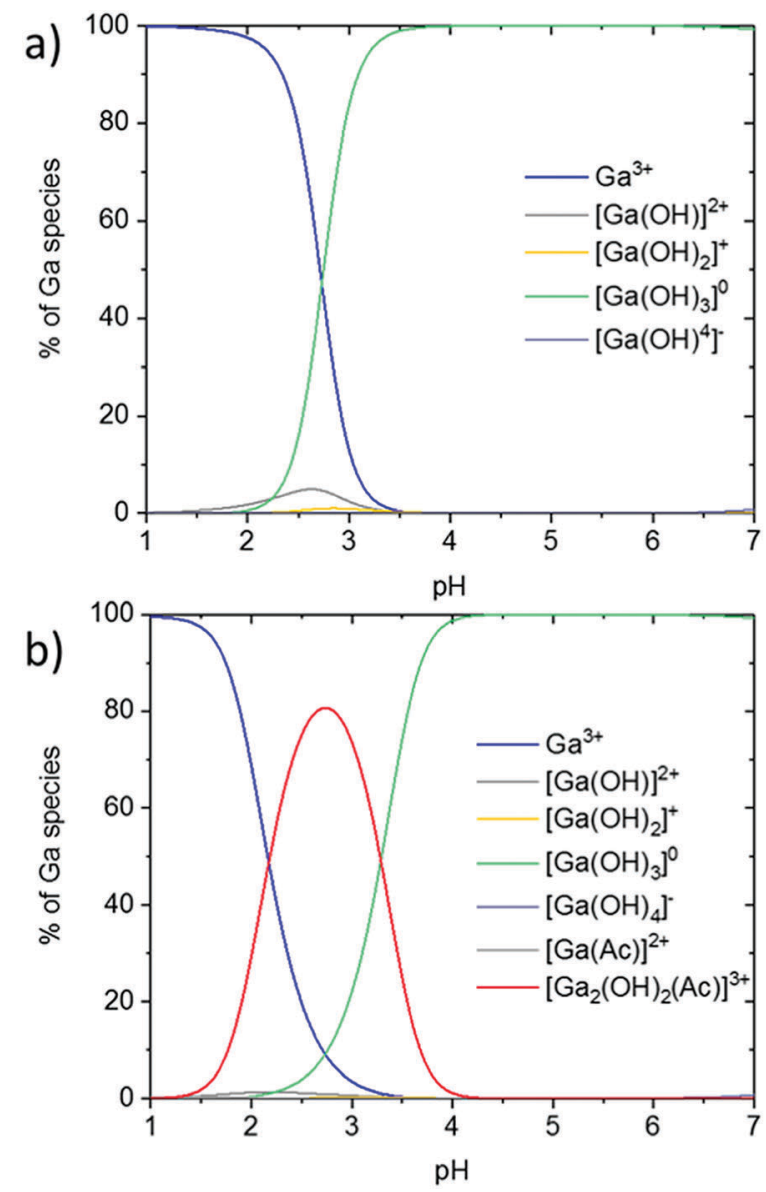

Fig. 1 Ga speciation without acetylacetonate ligands (a) in pure water and (b) in water + 3.5 M HAc.

alkaline environment, $\mathrm{Ga}^{3+}$ becomes soluble again in the form of $\left[\mathrm{Ga}(\mathrm{OH})_{4}\right]^{-}$.

To stabilize $\mathrm{Ga}^{3+}$ in acidic aqueous solutions and avoid $\mathrm{Ga}(\mathrm{OH})_{3}$ precipitation, complexation with chelate ligands results in thermodynamically stable gallium complexes. ${ }^{35}$ In spray pyrolysis, $\mathrm{Ga}^{3+}$ is often stabilized by acetylacetonate ligands, due to the volatile properties of the complex for a CVD-like film growth. ${ }^{36,37}$ Further, gallium acetylacetonate $\left(\mathrm{Ga}(\mathrm{acac})_{3}\right)$ is commercially available and a low-cost gallium precursor compound. A disadvantage of $\left(\mathrm{Ga}(\mathrm{acac})_{3}\right)$ is its low solubility in aqueous solutions.
Table 2 Solution compositions and calculated mean droplet size for spray pyrolysis at $360{ }^{\circ} \mathrm{C}$ and $0.8 \mathrm{ml} \mathrm{min}{ }^{-1}$ flow rate

\begin{tabular}{llllll}
\hline $\begin{array}{l}\mathrm{Ga}(\mathrm{acac})_{3} \\
(\mathrm{M})\end{array}$ & $\begin{array}{l}\text { Acetic } \\
\text { acid }(\mathrm{M})\end{array}$ & $\begin{array}{l}\mathrm{pH} \\
\text { value }\end{array}$ & $\begin{array}{l}\text { Surface } \\
\text { tension } \\
\left(\mathrm{mN} \mathrm{m}^{-1}\right)\end{array}$ & $\begin{array}{l}\text { Solution } \\
\text { density } \\
\left(\mathrm{g} \mathrm{ml}^{-1}\right)\end{array}$ & $\begin{array}{l}\text { Droplet } \\
\text { size }(\mu \mathrm{m})\end{array}$ \\
\hline 0.02 & 0.35 & 3.50 & 71.5 & 1.002 & 16.98 \\
0.02 & 3.50 & 2.41 & 60.5 & 1.025 & 16.06 \\
0.03 & 3.50 & 2.55 & 60.5 & 1.025 & 16.06 \\
0.04 & 3.50 & 2.61 & 60.5 & 1.025 & 16.06
\end{tabular}

Despite the fact that $\mathrm{Ga}(\mathrm{acac})_{3}$ is a very stable complex (see also the complex stability constants in Table 1), the ligands can be replaced by hydroxide ions in water-based solutions, as proposed in the literature. ${ }^{23,38}$ For this reason, acetic acid was added to additionally stabilize the $\mathrm{Ga}^{3+}$ ions in the solution by acetate-hydroxide complexes, as displayed in the speciation diagram in Fig. 1(b).

3.1.2 Precursor solution composition and spraying parameters. The precursor solution composition was optimized to obtain homogeneous films on glass substrates. As discussed earlier, the addition of acetic acid is necessary to stabilize the $\mathrm{Ga}^{3+}$ ions in the solution and avoid precipitates that lead to clogging of the ultrasonic nozzle and inhomogeneous film deposition. To accelerate the spraying process, the molarity of the solution has to be as high as possible, while achieving a complete dissolution of the precursor salts. Relevant solution compositions that were investigated are shown in Table 2 and microscope images of the deposited films on glass substrates are displayed in Fig. 2(a)-(d). If the solution contains only $0.35 \mathrm{M}$ acetic acid, a rough film morphology, due to droplet impact on the substrate, is observed (Fig. 2(a)), while the addition of $3.5 \mathrm{M}$ acetic acid guarantees adequate $\mathrm{Ga}^{3+}$ stabilization and homogeneous film growth from the gas phase (Fig. 2(b)).

The addition of acetic acid not only changes the Ga-species distribution, but it also decreases the surface tension $\gamma$ of the solvent, resulting in a smaller droplet size. The mean droplet

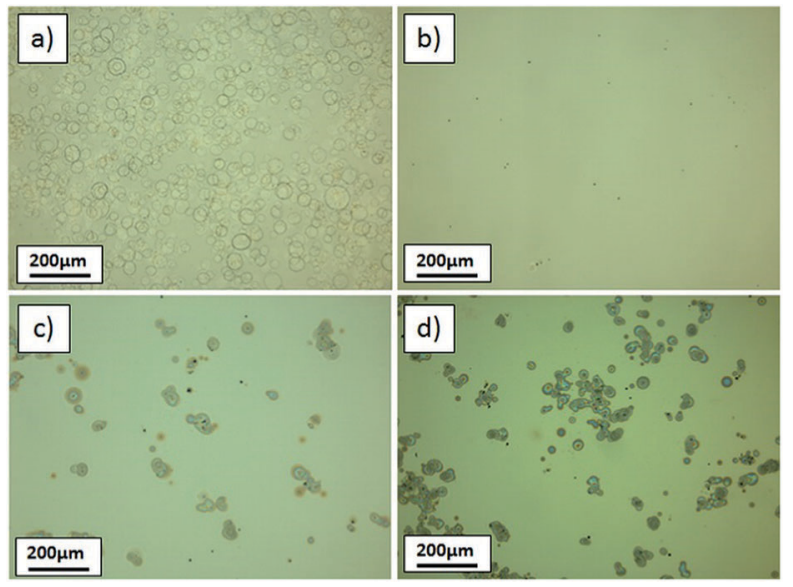

Fig. 2 Microscope images of sprayed $\mathrm{Ga}_{2} \mathrm{O}_{3}$ films on glass, obtained from the following solution compositions: (a) $0.02 \mathrm{M} \mathrm{Ga}(\mathrm{acac})_{3}+0.35 \mathrm{M} \mathrm{HAc}$, (b) $0.02 \mathrm{M} \mathrm{Ga}(\mathrm{acac})_{3}+3.50 \mathrm{M} \mathrm{HAc}$, (c) $0.03 \mathrm{M} \mathrm{Ga}(\mathrm{acac})_{3}+3.50 \mathrm{M} \mathrm{HAc}$, and (d) $0.04 \mathrm{M} \mathrm{Ga}(\mathrm{acac})_{3}+3.50 \mathrm{M} \mathrm{HAc}$. 

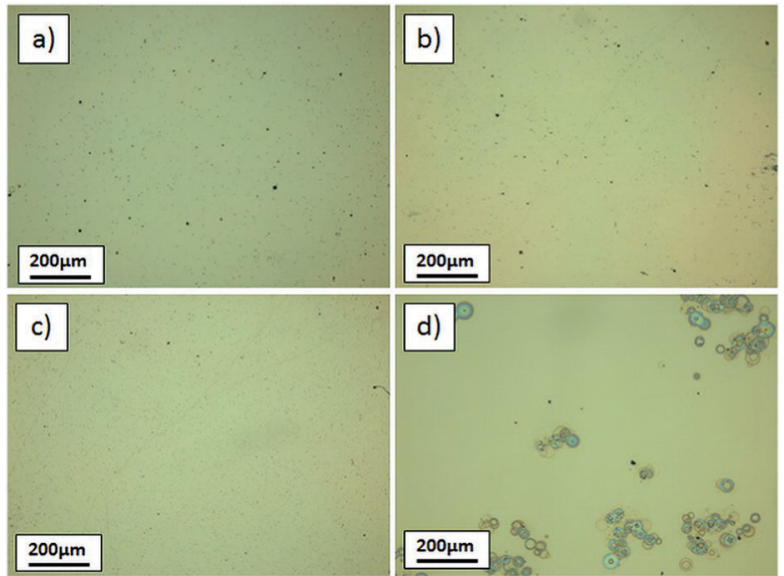

Fig. 3 Microscope images of sprayed $\mathrm{Ga}_{2} \mathrm{O}_{3}$ films deposited at the following temperature and flow rate values: (a) $380^{\circ} \mathrm{C}$ and $0.8 \mathrm{ml} \mathrm{min}^{-1}$, (b) $400{ }^{\circ} \mathrm{C}$ and $0.8 \mathrm{ml} \mathrm{min}-1$, (c) $380{ }^{\circ} \mathrm{C}$ and $1.2 \mathrm{ml} \mathrm{min}^{-1}$, and (d) $380{ }^{\circ} \mathrm{C}$ and $1.6 \mathrm{ml} \mathrm{min}{ }^{-1}$.

size generated by ultrasonic spray pyrolysis is given by Lang's equation: ${ }^{20}$

$$
d_{0}=0.34 \times\left(\frac{8 \pi \gamma}{\rho f^{2}}\right)^{0.33}
$$

where $\rho$ is the solution density $\left(\mathrm{g} \mathrm{ml}^{-1}\right), f$ is the excitation frequency $(\mathrm{Hz})$ and $d_{0}$ is the mean droplet size $(\mathrm{cm})$. The calculated mean droplet sizes for the various solutions are shown in Table 2. Surface tension and solution density were extracted from the literature values at $20{ }^{\circ} \mathrm{C} .{ }^{39,40}$ The higher acetic acid concentration decreased the mean droplet size by approx. $1 \mu \mathrm{m}$, with smaller solvent droplets requiring less heat for evaporation. Moreover, a high acetic acid concentration leads to the presence of the $\left[\mathrm{Ga}_{2}(\mathrm{OH})_{2} \mathrm{Ac}\right]^{3+}$ salt precursor, which has a higher decomposition rate than $\mathrm{Ga}(\mathrm{OH})_{3}$, which is mainly found at low acetic acid concentrations (Fig. 1).

For higher $\mathrm{Ga}(\mathrm{acac})_{3}$ concentrations and a nearly constant $\mathrm{pH}$ value, some precipitates were seen on the glass slides (Fig. 2(c) and (d)), which are most likely residues from incomplete decomposition of metal salts before reaching the hot substrate.

To maintain a reasonable growth rate of $\sim 1 \mathrm{~nm} \mathrm{~min}^{-1}$ and minimize the processing time, the solution composition of $0.04 \mathrm{M} \mathrm{Ga}(\mathrm{acac})_{3}$ and $3.5 \mathrm{M}$ acetic acid was used, and the unwanted precipitates were avoided through adjustment of equipment parameters. The critical parameter in ultrasonic spray pyrolysis is the temperature, since it is involved in all important processes such as aerosol transport, solvent evaporation and precursor decomposition. As the deposition temperature was increased from $360{ }^{\circ} \mathrm{C}$ (used in the previous experiments) to 380 and $400{ }^{\circ} \mathrm{C}$ (Fig. 3(a) and (b)), the precipitates disappeared.

To further accelerate the deposition and avoid substrate cooling during the process, the number of spraying cycles that yield the targeted film thickness must be minimized. This can be achieved by increasing the solution flow rate. The local temperature and the flow rate are inevitably connected, because a higher flow rate results in an increased substrate cooling with each spraying cycle. As the flow rate increased from $0.8 \mathrm{ml} \mathrm{min}{ }^{-1}$ to $1.6 \mathrm{ml} \mathrm{min}^{-1}$, precipitates start to appear again (see microscope image in Fig. 3(d)). Setting the flow rate at $1.2 \mathrm{ml} \mathrm{min}{ }^{-1}$ and the temperature at $380{ }^{\circ} \mathrm{C}$, a high-quality $\mathrm{Ga}_{2} \mathrm{O}_{3}$ film was obtained (Fig. 3(c)), and these parameters were defined as the standard conditions for all subsequent depositions on all substrates.

\section{2 $\mathrm{Ga}_{2} \mathrm{O}_{3}$ film characterization on glass and TCO substrates}

3.2.1 Structural properties. The SEM image of $\mathrm{Ga}_{2} \mathrm{O}_{3}$ sprayed from the optimized solution recipe on glass is shown in Fig. 4(a). The surface looks homogeneous with small grains, and the AFM image shows (Fig. 4(b)) a minor surface roughness with a root mean square (RMS) value of $2.66 \mathrm{~nm}$. Characteristically, 650 spraying cycles, amounting to a deposition time of $120 \mathrm{~min}$, resulted in a film thickness of $150 \mathrm{~nm}$.

To study the crystal structure of the $\mathrm{Ga}_{2} \mathrm{O}_{3}$ film, GIXRD diffractograms were recorded (Fig. 4(c)). As discussed before, the crystal structure of $\mathrm{Ga}_{2} \mathrm{O}_{3}$ depends on the growth method and conditions. $\mathrm{Ga}_{2} \mathrm{O}_{3}$ films deposited by spray pyrolysis are mostly amorphous ${ }^{21,23,24,26}$ or nanocrystalline. ${ }^{22}$ Monoclinic $\beta-\mathrm{Ga}_{2} \mathrm{O}_{3}$ was only reported for much higher processing temperatures $\left(>800{ }^{\circ} \mathrm{C}\right)^{12}$ or by including an additional annealing step $\left(>700{ }^{\circ} \mathrm{C}\right) .{ }^{21,23,24}$ The films in this study (Fig. 4(c)) show two broad reflections in the range of the monoclinic $\beta-\mathrm{Ga}_{2} \mathrm{O}_{3}$ phase (COD 96-200-4988) and a broad background peak for the a)

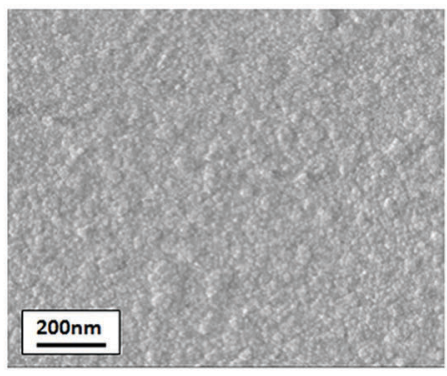

b)

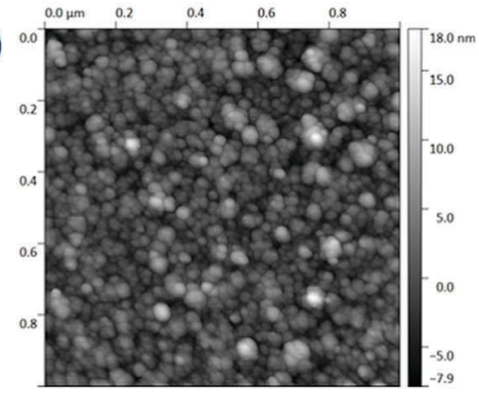

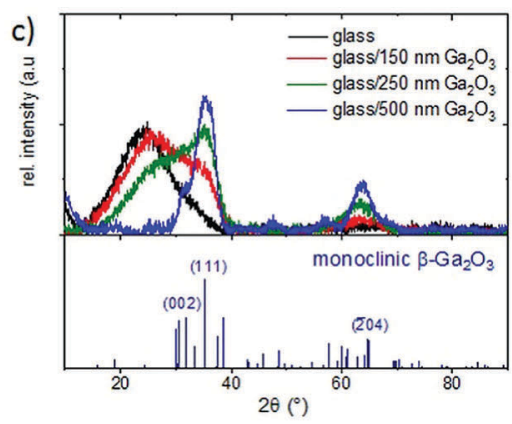

Fig. $4 \mathrm{Ga}_{2} \mathrm{O}_{3}$ film $\left(150 \mathrm{~nm}\right.$ ) deposited on borosilicate glass: (a) SEM image, (b) AFM image and (c) GIXRD $\left(1^{\circ}\right)$ including the monoclinic $\beta$-Ga $\mathrm{O}_{3}$ reference pattern. 

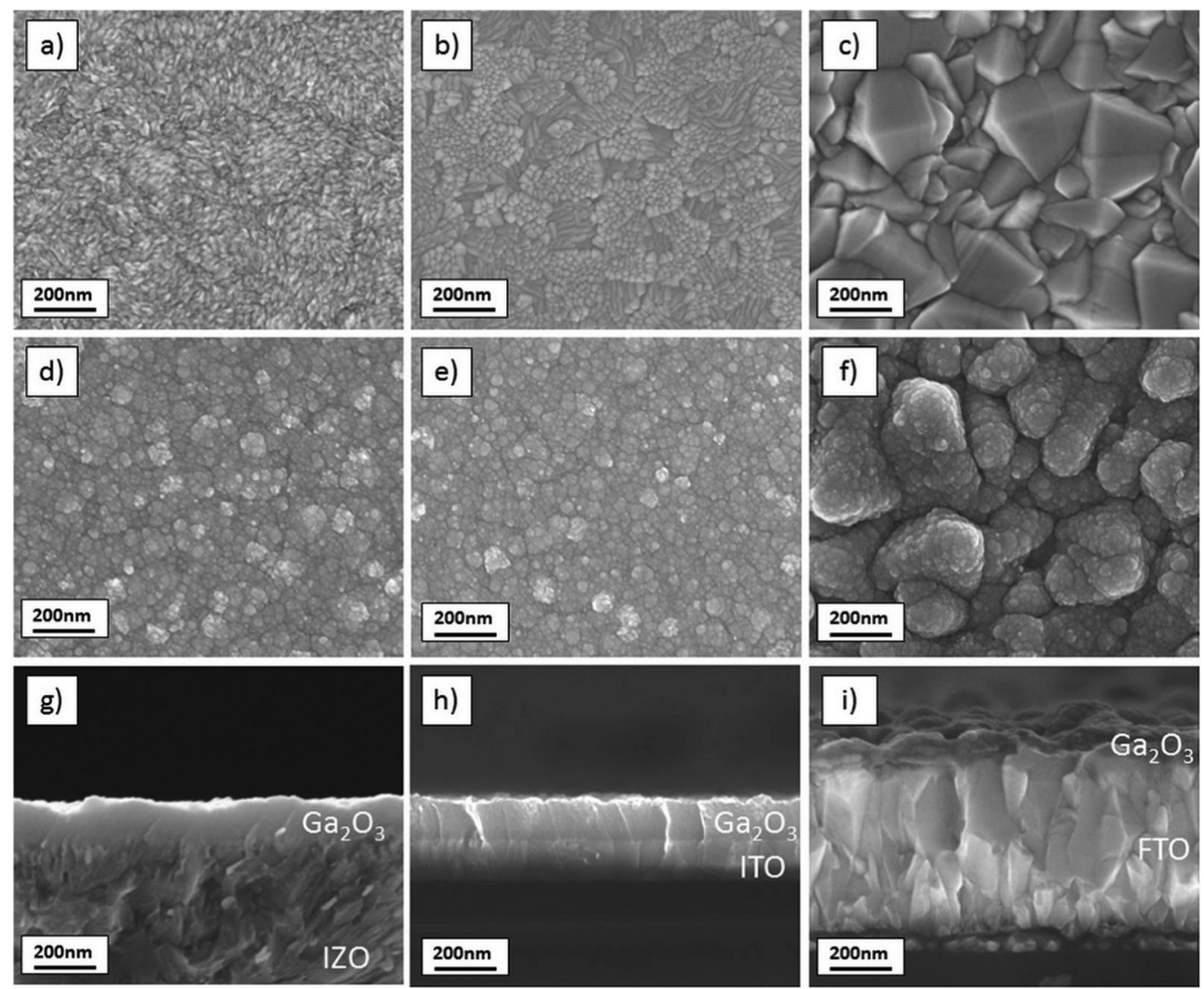

Fig. 5 SEM plane views of (a) IZO substrate, (b) ITO substrate, (c) FTO substrate, (d) IZO/ $\mathrm{Ga}_{2} \mathrm{O}_{3}$, (e) ITO/ $\mathrm{Ga}_{2} \mathrm{O}_{3}$, (f) $\mathrm{FTO} / \mathrm{Ga}_{2} \mathrm{O}_{3}$ and cross sections of (g) $\mathrm{IZO} / \mathrm{Ga}_{2} \mathrm{O}_{3}$, (h) ITO/ $\mathrm{Ga}_{2} \mathrm{O}_{3}$, and (i) $\mathrm{FTO} / \mathrm{Ga}_{2} \mathrm{O}_{3}$.

amorphous glass substrate. The first reflection can be assigned to the (111) $\beta-\mathrm{Ga}_{2} \mathrm{O}_{3}$ plane, while the second one cannot be assigned to a specific plane for $150 \mathrm{~nm} \mathrm{Ga}{ }_{2} \mathrm{O}_{3}$ films, due to the many possible plane reflections for the broad peak at $\sim 64^{\circ}$. For thicker films, the peak intensity increases and the reflection can be assigned to a specific plane. The broadness and weakness of the reflections support a film growth with crystallite sizes in the $\mathrm{nm}$ range. To minimize the intensity of the amorphous glass substrate peak in the XRD pattern, $\mathrm{Ga}_{2} \mathrm{O}_{3}$ films with $\sim 250$ and $500 \mathrm{~nm}$ thickness (1100 and 2200 spraying cycles) were deposited. With increasing film thickness, the (002) and (111) reflections, attributed to monoclinic $\beta-\mathrm{Ga}_{2} \mathrm{O}_{3}$, become more prominent. Additionally, the broad reflection around $64^{\circ}$ can be assigned to the ( $\left.\overline{2} 04\right) \beta-\mathrm{Ga}_{2} \mathrm{O}_{3}$ plane. The (111) and (204) reflections were used to calculate the crystallite size by the Scherrer formula, ${ }^{41}$ yielding 2.48 and $2.36 \mathrm{~nm}$, respectively. In conclusion, although other phases cannot be excluded, taking into account the relative stabilities of the possible phases and the peak positions, the monoclinic $\beta-\mathrm{Ga}_{2} \mathrm{O}_{3}$ phase predominates (as is more clearly demonstrated for thicker films), albeit with nanosized crystallites.

To investigate the influence of different substrates on the $\mathrm{Ga}_{2} \mathrm{O}_{3}$ film morphology, films were deposited on sprayed IZO, commercial ITO and FTO substrates. For many devices, such as in buffer layers in photovoltaics, $\mathrm{Ga}_{2} \mathrm{O}_{3}$ needs to be deposited on a TCO substrate. SEM pictures of the substrates with and without the $\mathrm{Ga}_{2} \mathrm{O}_{3}$ film are displayed in Fig. 5(a)-(f). It was observed that the $\mathrm{Ga}_{2} \mathrm{O}_{3}$ film morphology and grain size were not affected by the TCO substrate. Pinhole-free $\mathrm{Ga}_{2} \mathrm{O}_{3}$ grew homogenously, independent from the underlying TCO morphology. Small grain sizes between 10 and $20 \mathrm{~nm}$ were formed on IZO, ITO and FTO. On FTO, the large grains of the underlying substrate are still visible, but all of them are completely covered by $\mathrm{Ga}_{2} \mathrm{O}_{3}$. To further test that the film is hole-free, we drew macroscopic contacts $\left(\sim 4 \mathrm{~mm}^{2}\right.$ in area), using water-based conductive carbon paste, on the top of the $\mathrm{Ga}_{2} \mathrm{O}_{3}(20 \mathrm{~nm}$ thick). A bottom contact was also drawn on the TCO. We then measured the resistance between the bottom and top contacts, which was found to be in the region of $10 \mathrm{M} \Omega$ in the case of IZO and even larger for ITO.

SEM cross sections reveal the film growth in more detail (Fig. $5(\mathrm{~g})-(\mathrm{i})$ ). It appears that the $\mathrm{Ga}_{2} \mathrm{O}_{3}$ grows homogeneously as a nanocrystalline film on all substrates. The film thickness of $150 \mathrm{~nm}$ is independent of the substrate, which suggests a similar heat conductivity of all three TCOs, since temperature is one of the critical factors determining the film growth rate.

To investigate the crystal structure of $\mathrm{Ga}_{2} \mathrm{O}_{3}$ on the various substrates, GIXRD diffractograms at $1^{\circ}$ were recorded (Fig. 6(a)-(c)). On IZO, FTO and ITO substrates, no broad (111) $\beta-\mathrm{Ga}_{2} \mathrm{O}_{3}$ peak can be distinguished, because the (101) hexagonal 

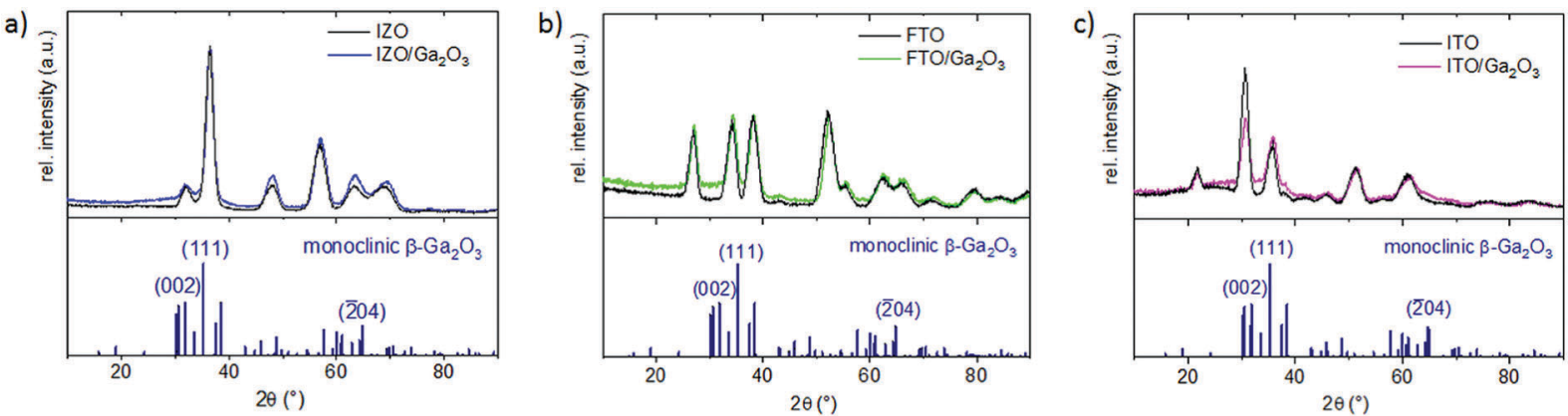

Fig. 6 XRD diffractograms of $\mathrm{Ga}_{2} \mathrm{O}_{3}$ films on TCO substrates including the monoclinic $\beta-\mathrm{Ga}_{2} \mathrm{O}_{3}$ reference pattern (a) on IZO, (b) on FTO, and (c) on ITO.

zinc(II) oxide, the (101) tetragonal tin(IV) oxide and the (400) cubic indium(III) oxide reflections are located at the same $2 \theta$ angle. In combination with the SEM pictures, it appears that the underlying TCO does not influence the growth of the $\mathrm{Ga}_{2} \mathrm{O}_{3}$ film.
Since the deposition of $\mathrm{Ga}_{2} \mathrm{O}_{3}$ on TCO substrates is a relevant step for device fabrication, like in photovoltaic cells, the sheet resistance of the three different TCOs after $\mathrm{Ga}_{2} \mathrm{O}_{3}$ deposition at $380{ }^{\circ} \mathrm{C}$ was measured. It was seen that for all three

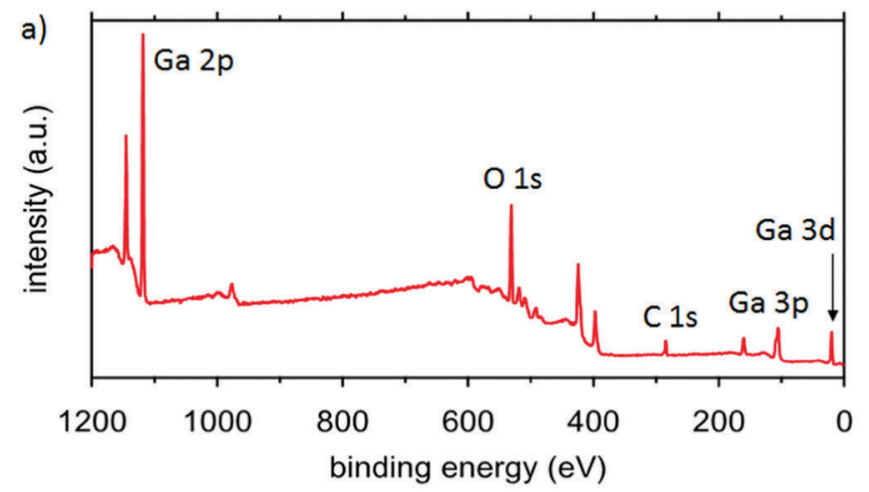

c) Ga $2 p$
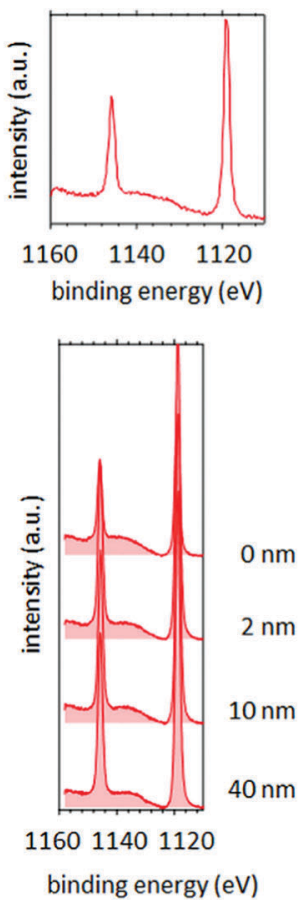

d) $\quad \mathrm{Ga} 3 \mathrm{p}$
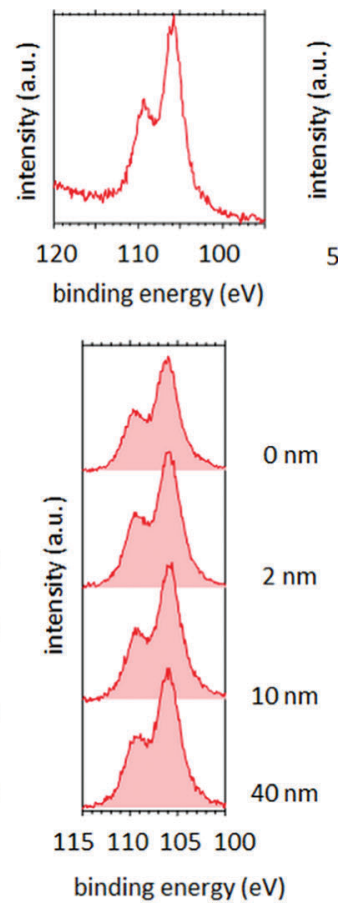

b)

Ga 3d

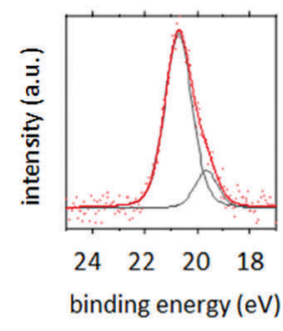

e) $01 \mathrm{~s}$
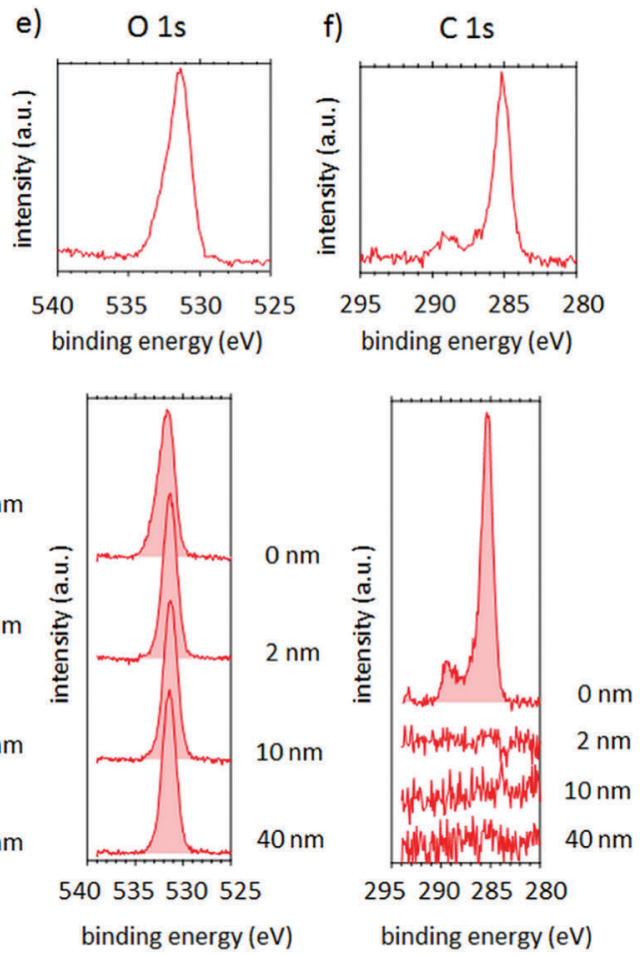

Fig. 7 (a) XPS analysis of $\mathrm{Ga}_{2} \mathrm{O}_{3}$ with (b) $\mathrm{Ga} 3 \mathrm{~d}$, (c) $\mathrm{Ga} 2 \mathrm{p}$, (d) Ga 3p, (e) $\mathrm{O}$ 1s and (f) $\mathrm{C}$ 1s core levels including XPS depth profiling. 
substrates, the deposition of $30 \mathrm{~nm} \mathrm{Ga}{ }_{2} \mathrm{O}_{3}$ (a usual buffer layer thickness in photovoltaic cells) did not modify the sheet resistance of the underlying TCO. The sheet resistance of IZO after the $\mathrm{Ga}_{2} \mathrm{O}_{3}$ deposition was $22.0 \Omega \mathrm{Sq}^{-1}, 5.8 \Omega \mathrm{Sq}^{-1}$ for FTO and $9.7 \Omega \mathrm{Sq}^{-1}$ for ITO. This shows that the used deposition conditions do not affect the conductivity of TCO, and they can therefore be applied on electrodes for device fabrication.

3.2.2 Elemental composition of the films. XPS was employed to investigate the chemical composition of the $\mathrm{Ga}_{2} \mathrm{O}_{3}$ film. The overview spectra in Fig. 7(a) and the single core levels Fig. 7(b-f) were measured on a sacrificial film grown on IZO and they clearly display strong signals arising only from $\mathrm{Ga}$ and $\mathrm{O}$. However, a rather small $\mathrm{C}$ 1s signal is present on the sample substrate. XPS depth profiling was performed via mild sputtering in order to provide a quantitative analysis of the film bulk and examine the chemical composition below the surface. The depth profiling clearly illustrated that no signal for carbon is detectable below the surface. Hence, the $\mathrm{C} 1 \mathrm{~s}$ peak at the surface is due to contamination.

Fig. 7(c)-(f) shows that the signal shape does not change depending on the depth, hence indicating the same chemical environment throughout the entire film. The signal ratio $\mathrm{Ga} / \mathrm{O}$ was calculated from the corresponding XPS signals to determine the film stoichiometry as a function of the depth. Table 3 shows that a ratio of about $50 \%: 50 \%$ for $\mathrm{Ga} 2 \mathrm{p}: \mathrm{O}$ 1s and $\mathrm{Ga}$ $3 \mathrm{p}: \mathrm{O} 1 \mathrm{~s}$ could be observed, indicating that the film is Ga-rich, suggesting the presence of two Gallium oxidation states, namely $\mathrm{Ga}(\mathrm{I})$ oxide $\left(\mathrm{Ga}_{2} \mathrm{O}\right)$ and $\mathrm{Ga}$ (III)oxide $\left(\mathrm{Ga}_{2} \mathrm{O}_{3}\right)$. The $\mathrm{Ga}$ 3d core level, displayed in Fig. 7(b) can be used to identify the ratio between $\mathrm{Ga}(\mathrm{I})$ (peak at $19.6 \mathrm{eV}$ in binding energy) and $\mathrm{Ga}$ (III) (at $20.6 \mathrm{eV}$ ). ${ }^{42}$ The peak area gives a ratio of $\mathrm{Ga}(\mathrm{III}): \mathrm{Ga}$ (I) of $85 \%: 15 \% \cdot \mathrm{Ga}_{2} \mathrm{O}_{3}$ is composed of $40 \% \mathrm{Ga}(\mathrm{III})$ and $60 \% \mathrm{O}$ and $\mathrm{Ga}_{2} \mathrm{O}$ is composed of $66.7 \% \mathrm{Ga}(\mathrm{I})$ and $33.3 \% \mathrm{O}$. Since $15 \% \mathrm{Ga}(\mathrm{I})$ and $85 \% \mathrm{Ga}(\mathrm{III})$ are present, this gives a signal ratio of $\mathrm{Ga}: \mathrm{O}$ of $44 \%: 56 \%$, which is in agreement with the ratio measured by XPS.

3.2.3 Optical properties. The optical properties were studied by UV/Vis/IR spectroscopy. To avoid UV absorption of the borosilicate glass and determine the optical band gap of $\mathrm{Ga}_{2} \mathrm{O}_{3}$, a film was deposited on a pure $\mathrm{SiO}_{2}$ glass substrate (see Fig. 8). From the transmittance spectrum, we constructed the Tauc plot $(a h \nu)^{n}$ versus $h \nu$, where $h \nu$ is the photo energy, $a$ is the absorption coefficient and $n=2$ for direct bandgap semiconductors. According to the relation $\alpha h \nu=A\left(h \nu-E_{\mathrm{g}}\right)^{1 / 2}$ ( $A$ is a constant), the abscissa of the linear extrapolation of the linear part of the plot gives the band gap of the film, which in this case is

Table 3 Composition of $\mathrm{Ga}_{2} \mathrm{O}_{3}$ in relation to film depth calculated from XPS data

\begin{tabular}{lllll}
\hline Depth $(\mathrm{nm})$ & Ga 2p (\%) & O 1s (\%) & Ga 3p $(\%)$ & O 1s (\%) \\
\hline 0 & 30.23 & 69.77 & 45.97 & 54.03 \\
1 & 46.9 & 53.1 & 50.7 & 49.3 \\
2 & 48.39 & 51.61 & 51.96 & 48.04 \\
5 & 49.12 & 50.88 & 52.14 & 47.86 \\
10 & 48.95 & 51.05 & 51.85 & 48.15 \\
40 & 49.28 & 50.72 & 52.22 & 47.78
\end{tabular}

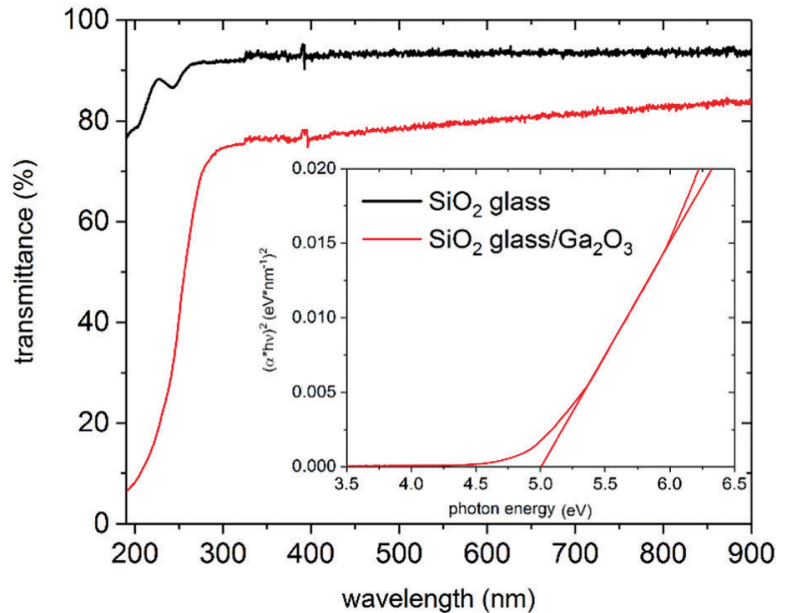

Fig. 8 Transmittance of $\mathrm{Ga}_{2} \mathrm{O}_{3}$ on pure $\mathrm{SiO}_{2}$ glass (inset shows the band gap).

$5.0 \mathrm{eV} .{ }^{43}$ The determined band gap value fits the literature data for spray deposited $\mathrm{Ga}_{2} \mathrm{O}_{3}$ films that range between 4.75 and $5.16 \mathrm{eV} .^{12,22-24}$ The large variations in band gap values may be due to differences in crystallite sizes, the crystal structure or film stoichiometry. For nanocrystalline $\mathrm{Ga}_{2} \mathrm{O}_{3}$ deposited by spray pyrolysis, a band gap of $4.91 \mathrm{eV}$ was reported $^{22}$ in agreement with the one reported in this work.

The transparency of the films on $\mathrm{SiO}_{2}$ substrates between 300 and $900 \mathrm{~nm}$ is above $70 \%$, and on borosilicate glass, it is above $80 \%$ (see Fig. 8 and $9(\mathrm{a})$ ). The thicker $\mathrm{Ga}_{2} \mathrm{O}_{3}$ film (250 nm) in Fig. 9(a) shows Fabry-Perot interferences, which are commonly observed in dense films. $\mathrm{Ga}_{2} \mathrm{O}_{3}$ films on TCO substrates (Fig. 9(b)-(d)) do not cause a change in transparency of the native substrate. On ITO substrates, the transparency in the UV region can be slightly improved through the $\mathrm{Ga}_{2} \mathrm{O}_{3}$ layer, which is probably caused by the effect of the elevated deposition temperature on the ITO film.
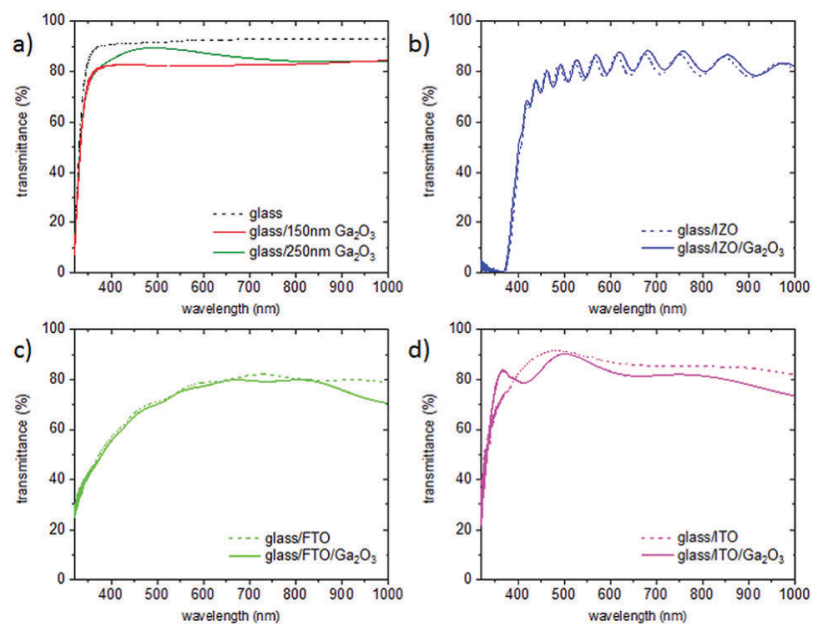

Fig. 9 Transmittance of $\mathrm{Ga}_{2} \mathrm{O}_{3}$ on various substrates: (a) borosilicate glass, (b) IZO, (c) FTO, and (d) ITO. 

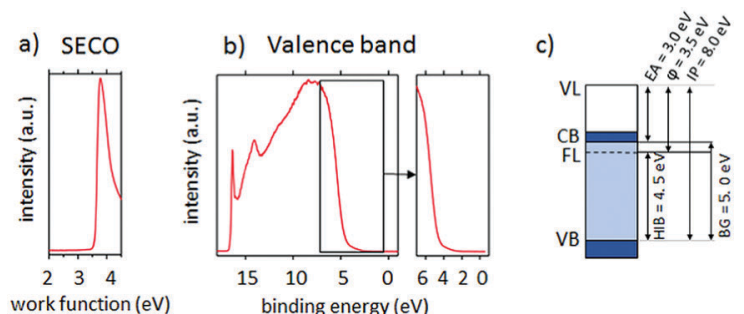

Fig. 10 UPS measurements of $\mathrm{Ga}_{2} \mathrm{O}_{3}$ (a) SECO, (b) valence band survey and (c) energy diagram.

3.2.4 Electronic properties and energy levels. UPS measurements were used to investigate the electronic valence region, determine the work function, and the valence band offset of the spray deposited $\mathrm{Ga}_{2} \mathrm{O}_{3}$. The work function $(\varphi)$ is the energetic distance between the Fermi level (FL) and the vacuum level (VL). A $\varphi$ of $3.5 \mathrm{eV}$ was measured via determination of the onset of the secondary electron cut-off (SECO), as displayed in Fig. 10(a). This value is in good agreement with the spray deposited $\mathrm{Ga}_{2} \mathrm{O}_{3}$ from an ethanol precursor solution reported by Thomas et $a .^{22}$ The electronic valence region was measured (Fig. 10(b)), and the position of the lowest occupied electronic levels was determined by linear regression of the onset, giving rise to a hole injection barrier (HIB) of $4.5 \mathrm{eV}$. The ionization potential (IP), calculated as the sum of $\varphi$ and HIB, was $8.0 \mathrm{eV}$. Since the optical band gap was determined as $5.0 \mathrm{eV}$, the electron affinity can be calculated as $3.0 \mathrm{eV}$, as displayed in the energy diagram Fig. 10(c).

\section{Conclusion}

In this study, we have shown how the composition of waterbased solutions and spray pyrolysis processing parameters have to be adjusted for the deposition of high-quality $\mathrm{Ga}_{2} \mathrm{O}_{3}$ films at temperatures below $400{ }^{\circ} \mathrm{C}$. Structural film properties were studied by GIXRD, AFM and SEM showing that the material is nanocrystalline $(\sim 2.4 \mathrm{~nm}$ grain size) with broad peaks that can be assigned to $\beta-\mathrm{Ga}_{2} \mathrm{O}_{3}$ and low surface roughness. XPS depth profiling revealed that the film is Ga-rich with $\mathrm{Ga}(\mathrm{III}): \mathrm{Ga}(\mathrm{I})$ in an $85 \%: 15 \%$ ratio. The work function, the electron affinity and the ionization potential of the spray deposited films were determined as $3.5,3.0$ and $8.0 \mathrm{eV}$. In order to demonstrate that $\mathrm{Ga}_{2} \mathrm{O}_{3}$ can be implemented in devices, homogeneous films were deposited on three different TCO substrates (IZO, ITO and FTO) without compromising the TCO sheet resistance and transparency.

\section{Conflicts of interest}

There are no conflicts of interest to declare.

\section{Acknowledgements}

We would like to thank Stefan Edinger and Lukas Kinner for fruitful discussions.

\section{References}

1 R. Roy, V. G. Hill and E. F. Osborn, J. Am. Chem. Soc., 1952, 74, 719-722.

2 J. B. Varley, J. R. Weber, A. Janotti and C. G. Van de Walle, Appl. Phys. Lett., 2010, 97, 142106.

3 S. J. Pearton, J. Yang, P. H. Cary, F. Ren, J. Kim, M. J. Tadjer and M. A. Mastro, Appl. Phys. Rev., 2018, 5, 11301.

4 J.-H. Park, R. McClintock, D. Pavlidis, F. H. Teherani, D. J. Rogers, B. A. Magill, G. A. Khodaparast, Y. Xu, J. Wu, V. P. Dravid and M. Razeghi, in Oxide-based Materials and Devices IX, International Society for Optics and Photonics, 2018, vol. 10533, p. 105330R.

5 E. Ohba, T. Kobayashi, M. Kado and K. Hoshikawa, Jpn. J. Appl. Phys., 2016, 55, 1202BF.

6 M. Higashiwaki, K. Sasaki, H. Murakami, Y. Kumagai, A. Koukitu, A. Kuramata, T. Masui and S. Yamakoshi, Semicond. Sci. Technol., 2016, 31, 34001.

7 A. K. Chandiran, N. Tetreault, R. Humphry-Baker, F. Kessler, E. Baranoff, C. Yi, M. K. Nazeeruddin and M. Grätzel, Nano Lett., 2012, 12, 3941-3947.

8 T. G. Allen and A. Cuevas, Phys. Status Solidi RRL, 2015, 9, 220-224.

9 T. Minami, Y. Nishi and T. Miyata, Appl. Phys. Express, 2013, 6, 44101.

10 Y. S. Lee, D. Chua, R. E. Brandt, S. C. Siah, J. V. Li, J. P. Mailoa, S. W. Lee, R. G. Gordon and T. Buonassisi, Adv. Mater., 2014, 26, 4704-4710.

11 T. Oshima, T. Okuno, N. Arai, N. Suzuki, S. Ohira and S. Fujita, Appl. Phys. Express, 2008, 1, 11202.

12 Z. Ji, J. Du, J. Fan and W. Wang, Opt. Mater., 2006, 28, 415-417.

13 Y. Tomm, J. M. Ko, A. Yoshikawa and T. Fukuda, Sol. Energy Mater. Sol. Cells, 2001, 66, 369-374.

14 M. Fleischer, L. Höllbauer and H. Meixner, Sens. Actuators, $B, 1994,18,119-124$.

15 S. Jin, X. Wang, X. Wang, M. Ju, S. Shen, W. Liang, Y. Zhao, Z. Feng, H. Y. Playford, R. I. Walton and C. Li, J. Phys. Chem. $C, 2015,119,18221-18228$.

16 Y. Lv, J. Ma, W. Mi, C. Luan, Z. Zhu and H. Xiao, Vacuum, 2012, 86, 1850-1854.

17 D. Guo, Z. Wu, P. Li, Y. An, H. Liu, X. Guo, H. Yan, G. Wang, C. Sun, L. Li and W. Tang, Opt. Mater. Express, 2014, 4, 1067-1076.

18 Q. Feng, F. Li, B. Dai, Z. Jia, W. Xie, T. Xu, X. Lu, X. Tao, J. Zhang and Y. Hao, Appl. Surf. Sci., 2015, 359, 847-852.

19 D. Choi, K.-B. Chung and J.-S. Park, Thin Solid Films, 2013, 546, 31-34.

20 R. Rajan and A. B. Pandit, Ultrasonics, 2001, 39, 235-255.

21 R. Pandeeswari and B. G. Jeyaprakash, Sens. Actuators, B, 2014, 195, 206-214.

22 S. R. Thomas, G. Adamopoulos, Y.-H. Lin, H. Faber, L. Sygellou, E. Stratakis, N. Pliatsikas, P. A. Patsalas and T. D. Anthopoulos, Appl. Phys. Lett., 2014, 105, 92105.

23 P. Wu, Y.-M. Gao, R. Kershaw, K. Dwight and A. Wold, Mater. Res. Bull., 1990, 25, 357-363. 
24 A. Ortiz, J. C. Alonso, E. Andrade and C. Urbiola, J. Electrochem. Soc., 2001, 148, F26-F29.

25 H. Kim and W. Kim, J. Appl. Phys., 1987, 62, 2000-2002.

26 J. Hao and M. Cocivera, J. Phys. D: Appl. Phys., 2002, 35, 433.

27 E. Arca, K. Fleischer and I. V. Shvets, J. Phys. Chem. C, 2009, 113, 21074-21081.

28 N. Winkler, S. Edinger, J. Kaur, R. A. Wibowo, W. Kautek and T. Dimopoulos, J. Mater. Sci., 2018, 53, 12231-12243.

29 S. A. Wood and I. M. Samson, Ore Geol. Rev., 2006, 28, 57-102.

30 Aqueous solutions, http://www.acadsoft.co.uk/aq_solutions. htm, accessed July 9, 2018.

31 P. L. Brown, J. Chem. Soc., Dalton Trans., 1989, 399-402.

32 I. Tóth, L. Zékány and E. Brücher, Polyhedron, 1984, 3, 871-877.

33 M. Clausén, L.-O. Öhman, J. D. Kubicki and P. Persson, J. Chem. Soc., Dalton Trans., 2002, 2559-2564.

34 J. Stary and J. O. Liljenzin, Pure Appl. Chem., 2009, 54, 2557-2592.
35 W. R. Harris and A. E. Martell, Inorg. Chem., 1976, 15, 713-720. 36 J. C. Viguié and J. Spitz, J. Electrochem. Soc., 1975, 122, 585-588. 37 P. Marchand and C. J. Carmalt, Coord. Chem. Rev., 2013, 257, 3202-3221.

38 W. J. DeSisto, Y.-T. Qian, C. Hannigan, J. O. Edwards, R. Kershaw, K. Dwight and A. Wold, Mater. Res. Bull., 1990, 25, 183-189.

39 E. Álvarez, G. Vázquez, M. Sánchez-Vilas, B. Sanjurjo and J. M. Navaza, Surface Tension of Organic Acids + Water Binary Mixtures from $20{ }^{\circ} \mathrm{C}$ to $50{ }^{\circ} \mathrm{C}$, https://pubs.acs.org/ doi/abs/10.1021/je970025m, accessed July 11, 2018.

40 Density of aqueous solutions of organic acids, https://www. engineeringtoolbox.com/density-aqueous-solution-formiclactic-oxalic-acetic-citric-acid-concentration-d_1953.html, accessed July 11, 2018.

41 A. L. Patterson, Phys. Rev., 1939, 56, 978-982.

42 R. Carli and C. L. Bianchi, Appl. Surf. Sci., 1994, 74, 99-102. 43 J. Tauc, Mater. Res. Bull., 1968, 3, 37-46. 